Научна критика

УДК 930.85(44)(049.32)

94(44)(049.32)

Примљен: 22. марта 2021.

Прихваћен: 23. марта 2021.

https://doi.org/10.46630/phm.13.2021.68

\title{
ПРИЧА О ФРАНЦУСКОМ КУЛТУРНОМ НАСЛЕБУ ОД РОМАНИЗОВАНЕ ГАЛИЈЕ ДО РЕНЕСАНСНЕ ФРАНЦУСКЕ
}

(Nermin Vučelj, Francuska kultura: jezik, društvo i duhovnost kroz epohe. Od romanizovane Galije do renesansne Francuske, Filozofski fakultet, Niš, 2020, 341 str.)

Монографија Франиуска култура: језик, друштво и духовност кроз епохе др Нермина Вучеља, ванредног професора на Департману за француски језик и књижевност Филозофског факултета у Нишу, представља прву књигу у промишљању историје француске духовности, која обухвата хронолошки период, како јој и поднаслов каже, од романизоване Галије до ренесансне Француске. Монографија се састоји од осам поглавља (од којих свако има више потпоглавља): 1. Култура (13-22), 2. Галија (23-56), 3. Франачка (57-80), 4. Франиуска у доба Kапета (81-140), 5. Англо-франиуске везе од 11. до 14. века (141-162), 6. Стогодишьи рат 1337-1453. (163-192), 7. Хуманистички покрет у Франиуској (193-234) и 8. Реформација и верски ратови (235-284), којима претходи текст Уместо предговора (11-12), а које затвара текст Уместо поговора: Монтень и Ла Боеси (285-292). Монографија је употпуњена и опсежном Библиографијом (295-304), Белешком о аутору (293), те корисним пописом Index nominum (305-341), који представља, више од пуког индекса имена, енциклопедијски додатак о важним личностима из француске културе и историје.

У тексту Уместо предговора аутор ставља до знања који су циљеви и претпостављени домети тог дијахонијског путовања кроз историју Француске од њених почетака до ренесансних времена, као и коме је она намењена, подвлачећи да је у питању његов лични поглед, који је „индивидуалан - али не приватан, субјективан - али не пристрасан, свеобухватан - али не исцрпан, страствен према предмету разматрања - али не и острашћен” (11).

Прво, опште поглавље, насловљено Култура, бави се детаљним дефинисањем појма култура, како у ужем тако и у ширем значењу, као и његовим разграничењем са сродним појмом иивилизаиија. Даље аутор дефинише одредницу француска култура, која је предмет његове студије, 
образлажући при том и сам наслов, који „културу одређује као историју цивилизације, као дух епохе и као уметничко стваралаштво, те најављује историографска и социолошка, филолошка и естетичка, философска и етичка сагледавања једне културе у хронолошком низу, у одређеном географском забрану и на једном језику, а што зовемо - француска култура" (19). Најзад, сагледавајући развој културе кроз епохе, Вучељ подвлачи разлику која постоји између онога што зовемо општом културом, која је била важна одлика појединаца у минулим временима, и онога што се означава појмом општа информисаност, која преовладава у наше доба.

Друго поглавље, Галија, детаљно се бави историјом територије данашње Француске у доба када су је насељавали Келти, одн. Гали. Будући да о том периоду нема много историјски поузданих сведочанстава, Вучељ даје преглед историографије која се тиме досада бавила. Аутор се детаљно бави римским освајањем Галије, њеном поделом и романизацијом, пратећи на том историјском путу освајача Гаја Јулија Цезара и његове Записе о Галском рату, али настојећи да да̂ објективан приказ тог времена кроз преиспитивање свих доступних извора о том добу. Анализирајући „језик галског духа и дух галског језика” и њихово присуство у савременом француском језику и идентитету, Вучељ се детаљно бави крилатицом „Гали, наши преци”, истичући да се ради о историјско-политичком клишеу који је ушао у „у школску подуку почев од 1867. године, а модерни политички мит 'о Верцингеториксу као националном јунаку, мученику и симболу освете', како га одређује Дитлер (1994: 591), послужио је за колективни психолошки трансфер у лечењу националне фрустрације настале из пораза у рату с Прусима 1870. године, након којег је Француска изгубила територије на истоку, Алзас и Лорену, а које ће повратити тек после Првог светског рата” (54). Будући да „теза о галском пореклу Француза јесте политички мит” (54), Вучељ истиче да је француско наслеђе троструко: галско, римско и германско (55).

У трећем поглављу, Франачка, аутор се бави периодом раног средњег века у историји територије на којој се налази данашња Француска, када варварска германска племена освајају римске провинције и када настаје прва организована држава на том тлу, истичући да је најмоћније међу њима, Франци, освојило територију, наметнуло своју управу и моћ, дајући „своје име народу који ће се профилисати цивилизацијски на територији коју је оно било запосело, као и језику којим ће он говорити, али не и са̂м језик" (79). Није ни случајно што ће касније настати и мит о библијском пореклу Француза (првенствено захваљујући Ронсаровом епу Франсијада), „од библијског Ноја као оца Гала и од Тројанца Франкуса као оца Франака”, због чега је „француска нација у привилегованим друштвеним круговима на себе гледала као на баштиника класичне ан- 
тике, наследника, тиме и природног настављача, старогрчке и латинске традиције, чиме се хранила национална охолост у 17. веку, у време апсолутистичке владавине Луја XIV и у доба mainstream књижевности зване класицизам" (63). Вучељ анализира узроке и последице тог освајања и приказује хронологију стварања франачке државе, од њених првих краљева, Хлодовеха и Дагоберта, па све до Карла Великог и обнове Светог римског царства, када се оснивају прве школе и манастири и извршава потпуна христијанизација, што све доприноси развоју познатом у историји као Каролиншка ренесанса, неколико векова пре Ренесансе, када ће, у манастирима и скрипторијима, настати каролиншки рукописи и преводи дела из класичне старине, преко којих ће италијански хуманисти „поново откривати класичну књижевност” (72). Такође, посебно истиче да је то доба време настанка првих писаних споменика (Стразбуршке заклетве из 842. године) и првих књижевних дела (Кантилена о светој Еулалији, Житије светог Алексија и Житије светог Лежеа) на новонасталом романском, одн. касније старофранцуском језику, што представља почетке француске књижевности.

У четвртом поглављу, Франиуска у доба Капета, детаљно је анализирано раздобље од 11. до 14. века, доба када Франачка постаје Француска, што је, по неким историчарима, почетак француске историје, иако почетак многи виде и у ранијим периодима (галско доба, Хлодовехово доба, распад франачке државе након смрти Карла Великог). Овај период „старе Француске” од 987. во 1328. веома је разноврстан, узбудљив и драматичан и обухвата период од крунисања Хуга Капета па све до пред почетак Стогодишњег рата. Како је тај период познат као време Крсташких ратова, аутор даје детаљан попис тих ратова, посебно говорећи о њиховом карактеру, уз закључак да „када се слика друштвено-политички портрет Француске одређених периода, онда националну слику треба представити у временском контексту са свим размерама дивота и страхота које је чине, приказати је из свих постојећих и могућих углова, и радије, уместо понуђених закључака, омогућити разумевање догађаја, њихових узрока, произведених последица и изведених поступака" (139), уз опаску да ни наше време није лишено страхота иако смо вековима удаљени од „мрачног” средњег века, те да „пре него што видимо назадност и нечовечност као обележје одређене историјске епохе, поразмислимо колико те одреднице пристају и епохи из које долази онај који расправља о прошлим зверствима" (98). Велику пажњу у овом поглављу Вучељ посвећује прогону „јеретика”, настанку градова и универзитета̂, развоју језика̂, apхитектуре и књижевности, са посебним нагласком на настанак витештва у средњем веку, анализирајући, што је ретка посебност ове монографије, епског витеза, витезове Темпларе, те настанак култа Госпе и куртоазни 
дух дворског витеза, који ће своје најлепше отелотворење доживети у лирици трубадура и трувера, те витешким романима Кретјена де Троаа.

Период од 11. до 14. века је време успостављања веома блиских али и погубних односа између Француске и Енглеске, који ће резултирати Стогодишњим ратом и великим борбама за француски престо. Зато се у овом делу Вучељ детаљно бави, осим Хугом Капетом, личностима заједничким историјама Француске и Енглеске, као што су Алиенора Аквитанска, Виљем Освајач, Луј VII, Хенрик II Плантагенет, Ричард Лављег Срца, који је „био више Француз него Енглез, а за њим ће се још два века Енглези из виших друштвених слојева радо правити Французима и међусобно споразумевати на старофранцуском језику, док ће матични средњеенглески препустити на употребу нижим друштвеним слојевима" (82). Још детаљније ће се на те односе осврнути у петом поглављу, Англо-

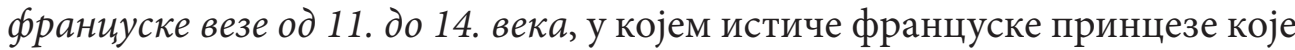
су постале енглеске краљице (њих 13), а посебно се бави контрастивним односом између (старо)француског и (средње)енглеског језика, указујући да „енглески језик $60 \%$ речи у свом речничком корпусу дугује француском и латинском, и да је, према томе, енглески најлатинскији међу германским језицима”, док „у француском језику је број позајмљеница из енглеског на процентуалном нивоу од 5\%” (147).

Везе Француске и Енглеске предмет су ауторовог интересовања и у шестом поглављу, Стогодишњи рат 1337-1453, у коме промишља разлоге, узроке и последице једновековних сукоба две нације у династичком спору око француске круне, разлажући их на две етапе (1337-1380. и 1380-1453), са посебним освртом на живот, дело и постхумну славу ратнице и потоње светитељке Жане д’Арк, познатије код нас као Јованка Орлеанка. Такође, предмет ауторовог интересовања у овом поглављу су и личност и дело француског принца и песника Шарла Орлеанског, који ће надахнути песнике симболизма у 19. веку, када, након вишевековног заборава, буде поново откривен, али и настанак библиотека и преводилаштва као наговештај хуманизма који ће се јавити у 16. веку.

Хуманистички покрет у Франиуској предмет је интересовања седмог, тако и насловљеног, поглавља. Вучељ се у уводном делу овог поглавља бави дефинисањем и разграничењем кључних појмова француског 16. века, а то су хуманизам и ренесанса: „хуманизам је покрет заснован на једном идеалу, из чега се изводи образовни програм, начела научног истраживања, естетско образовање и етичко делање; а ренесанса је стваралачки и уметнички производ хуманистичког покрета. Тако су хуманизам и ренесанса узајамно постављени као идеал и његово остварење" (199). Кроз приказ тзв. Италијанских ратова, он показује како италијански хуманистички дух прелази на територију Француске и како се у њој шири 
и развија, у време владавине краља Франсоа I, заслужног и за оснивање Колегијума краљевских лектора, као и за проглашење тадашњег француског званичним језиком администрације краљевине Указом из ВилерKompea (Ordonnance de Villers-Cotterêts, 1539). Све то је омогућило развој хуманистичког покрета и настанак Ренесансе, која ће изнедрити неке од највећих француских стваралаца (Раблеа, Ди Белеа, Ронсара, Монтења, Маргерите Наварске), али и важну етапу у развоју француског језика обележену песничком групом Плејада, чији ће спис Одбрана и величаtьe фрраниуског језика (La Défense et illustration de la langue française), који je 1549. написао песник Ди Беле, представљати прекретницу у историји француске књижевности и француског језика. Захваљујући свему томе, Француска је у 16. веку искорачила из средњег века и крупним корацима закорачила у модерно доба. Оно што је нарочито значајно у овом поглављу јесте ауторов излазак из уско европских визура како би показао да је и другде у свету било таквих раздобља, само се о њима мало или недовољно зна и говори (нпр. Кина и арапски свет), истичући да је арапска цивилизација „од 8. до 11. века живела своје класично доба” док је „Европа обитавала у средњовековној инфериорности”, те да „муслиманска наука и култура, отворене за спољне утицаје, према Бернарду Луису (LUIS 2004: 337) - највише грчке, затим персијске, те индијске и кинеске, цветале су, док је хришћански запад, затворен према другима и самодовољан, научно, медицински и хигијенски био инфериоран у односу на цивилизацију против које је покренуо крсташке походе" (193). А онда се са хуманизмом дешава преокрет: док се затворене западне хришћанске културе отварају и доживљавају цивилизацијски напредак, истодобно се источне муслиманске културе окрећу себи, самоизолују се и затварају, и на тај начин назадују. Тиме он даје ширу слику света у доба препорода и европског враћања античким узорима, те човеку као средишту и мерилу свих ствари. Узроке тог напретка Вучељ види у „три велика догађаја: први - откриће новог света [...]; други - ренесанса као период поновног откривања класичне антике; трећи - почетак реформаторског покрета" (195). Велику улогу у свему имало је и изумевање штампарске машине.

Осмо поглавље, Реформација и верски ратови, такође се бави драматичним догађајима у 16. веку. Аутор дефинише кључне појмове за разумевање верских сукоба у том периоду, а то су ребормащија, лутеранство, калвинизам, протестанти и хугеноти, а помно се бави шизмом између католика и протестаната, верском нетолеранцијом и дворским сплеткама, који су довели до крваве Вартоломејске ноћи 24. августа 1572. године, након венчања хугенота Анрија Наварског и католикиње Маргарите де Валоа, као и каснијим покушајима помирења који су довели до усвајања Нантског едикта 1598, питајући се „може ли се говорити о пра- 
вој верској и личној слободи ако је она сведена на неколико резервата за протестанте”, али са закључком да, „и поред тога, проглашење Нантског едикта од великог је политичког значаја" (255) јер представља први корак ка помирењу. Нарочиту пажњу аутор посвећује „добром краљу Анриjу", Анрију од Наваре, тј. краљу Анрију IV, као и његовој првој супрузи (сестри краљева Франсоа II, Шарла IX и Анрија III), а касније краљици Маргарити де Валоа, познатијој у литератури под надимком краљица Марго. Вучељ наглашава да су постојале три значајне личности у француској историји које су се звале Маргарита де Валоа, те даје прецизну разлику између њих: „ради јасног разликовања три бисера из породице Валоа, остаје да прва Маргарита јесте Наварска - ренесансна списатељица и сестра Франсоа I, да друга Маргарита јесте Савојска - кћерка Франcoa I, братаница оној првој, и војвоткиња у Савоји, и да трећа Маргарита јесте Валоа, кћерка Катарине де Медичи, братаница другој Маргарити, и прва супруга краља Анрија IV. Трећа Маргарита носи надимак Марго (Margot)" (271-272). Причом о краљици Марго, унуци Франсоа I, Вучељ завршава своју студију.

Прва књига монографске студије Франиуска култура: језик, друштво и духовност кроз епохе др Нермина Вучеља, гледано у целини, оправдава темељну замисао, да буде „уџбеник, приручник и(ли) подсетник” који је „намењен људима од духа, интелектуално радозналим, и студентима" (12). Међутим, својим обимом, обухватношћу, начином приказа, полемичким тоном и присутношћу других и другачијих мишљења, она ту замисао и превазилази, нарочито ако се упореди са другим сличним делима на исту тему у домаћој франкороманистици (пример изузетно цењене и незаобилазне Франиуске цивилизације Гордане и Слободана Витановића из 1994). Ову монографију одликује изузетно познавање грађе, позивање на велики број извора и научних студија, компарација, оспоравање и полемисање са њима, али и посебан стил којим је она писана. Иако је неоспорно да је реч о научној и стручној монографији, она се чита као узбудљива и драматична прича о историји Француске (и не само ње), јер, слично једном од поменутих узора, Монтењу, Нермин Вучељ „не подучава, него прича" (286). Аутор се каткад, како би употпунио своју анализу и дао шири поглед, користи и примерима из фикцијских дела, књижевних и кинематографских, што даје нов и свеж дах причи, а за сваку похвалу су и препеви Ронсарове лирике у поглављу о хуманизму и Ренесанси.

Посебно треба истаћи да Вучељ, пишући о бурним временима у историји Француске, не пропушта да укаже и на лоше стране наше епохе и друштва, које често мисли да је, захваљујући чињеници да је технички и технолошки напредовало, напредовало и у сваком другом погледу, 
што, ако се узму у обзир сва разарања у нашем времену, уништавање класичног образовања и индивидуалног развоја, као и пад свих, а нарочито моралних, вредности, мора да се доведе у питање. У завршном тексту, Монтень и Ла Боеси, замишљеном као замена за поговор, Вучељ анализира спис осамнаестогодишњег хуманисте из 16. века, Етјена де Ла Боесија, Расправа о доброволном ропству (Étienne de La Boétie, Discours de la servitude volontaire), у коме млади писац говори како „под тиранима људи лако постају кукавице и мекушци” (291) и како су лако спремни да изгубе слободу, иако су поробљени „од стране једног јединог човека који није ни Херакле ни Самсон, већ човечуљак” (290) који успављује „поданике површним забавама, игром и спектаклом, што је истовремено мамац за подјармљене људе и цена за изгубљену слободу" (291). У таквом свету, сматра Ла Боеси, а и Вучељ с њим, „човек је лишен људских својстава - саосећања, солидарности, моралног поступања, духовног уздизања и естетског доживљаја”, па зато „на појединцу је да у себи пронађе успавани зов слободе и истине, да га покрене, да поврати људско достојанство и обнови лепоту и вредност човечног. Да бисмо били самосвесни грађани, а не поданици, слободни људи, а не контролисани роботи, важно је (само)образовање с правим компасом који показује смер лепог, доброг и истинитог, и да следимо тај пут у свему што радимо” (292). Читамо анализу текста писца из 16. века и не можемо да се отмемо утиску да се ништа за пола миленијума није суштински променило, упркос огромном напретку технике. Стога је и Вучељева књига не само приказ минулих времена, већ и позив на размишљање о вредностима и суштини постојања и савременог човека. Тиме она увелико превазилази задати научностручни оквир.

Због свега реченог, монографија Франиуска култура: језик, друштво и духовност кроз епохе. Од романизоване Галије до ренесансне Франиуске Нермина Вучеља представља незаобилазно штиво свима онима који се занимају за бурну историју (Западне) Европе, али и путоказ савременом човеку, чиме представља значајан допринос домаћој франкороманистици. Са нестрпљењем очекујемо њен најављени наставак.

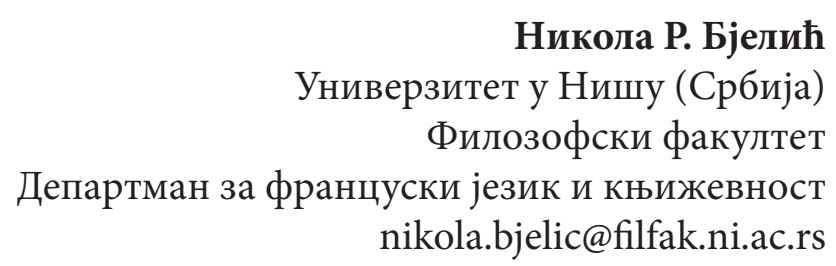

